\title{
Influence of physiotherapy on severity of motor symptoms and quality of life in patients with Parkinson disease
}

\section{Wpływ systematycznie prowadzonej fizjoterapii na nasilenie objawów ruchowych oraz jakość życia u osób z chorobq Parkinsona}

\author{
Joanna Cholewa', Magdalena Boczarska-Jedynak2, Grzegorz Opala²
}

IAkademia Wychowania Fizycznego im. J. Kukuczki w Katowicach

2Klinika Neurologii Śląskiego Uniwersytetu Medycznego w Katowicach

Neurologia i Neurochirurgia Polska 2013; 47, 3: 256-262

DOI: 10.5114/ninp.2013.35774

\section{Abstract}

Background and purpose: Parkinson disease (PD) is one of the most frequent diseases of the central nervous system. Rehabilitation is one of the factors which may help the patients to maintain higher physical activity in everyday life. The aim of this work was to evaluate the influence of movement rehabilitation on severity of motor symptoms in PD patients.

Material and methods: The study included 70 patients suffering from PD according to the Hoehn and Yahr scale. Patients' clinical status was assessed with Unified Parkinson's Disease Rating Scale (UPDRS) parts I-III. Additionally, activity of daily living was evaluated with the Schwab and England scale. The quality of life was evaluated by the Parkinson's Disease Questionnaire (PDQ-39). The examinations were conducted before and after the twelve weeks of the experiment. Patients included in the intervention group $(n=40)$ took part in 60-minute rehabilitation exercises twice a week, which were aimed at increasing movement ranges, balance improvement, movement agility and walking. The main emphasis was placed on the ability to cope with daily activities.

Results: A significant difference in scores of given scales before and after the 12-week period was observed in the intervention group: UPDRS part I score decreased by $17.31 \%$, part II decreased by $22.2 \%$, part III decreased by $18.96 \%$,

\section{Streszczenie}

Wstęp i cel pracy: Choroba Parkinsona (ChP) jest jedną z najczęstszych chorób ośrodkowego układu nerwowego. Rehabilitacja ruchowa to jeden z czynników, które mogą pomóc pacjentowi utrzymać większą sprawność i pozwalają lepiej funkcjonować na co dzień. Przedstawiane w piśmiennictwie badania w sposób niejednoznaczny określają rolę postępowania rehabilitacyjnego w leczeniu osób z ChP, dlatego celem pracy było określenie wpływu rehabilitacji ruchowej na stopień nasilenia objawów ruchowych $\mathrm{ChP}$.

Materiał i metody: W badaniach uczestniczyło 70 osób cierpiących na $\mathrm{ChP}$ w III stopniu zaawansowania choroby wg skali Hoehn i Yahra. Dla określenia stanu klinicznego zastosowano Ujednolicona Skale Oceny Choroby Parkinsona (Unified Parkinson's Disease Rating Scale [UPDRS], część I, II i III). Dodatkowo przeprowadzono ocenę czynności codziennych skalą Schrwab and England Activities of Daily Living. Oceniono również jakość życia chorych skalą The Parkinson's Disease Questionnaire (PDQ-39). Ocenę przeprowadzono na początku badania i po 12-tygodniowym eksperymencie. Badana grupa pacjentów ( $n=40)$ uczestniczyła w zajęciach rehabilitacyjnych dwa razy w tygodniu po 60 minut. Zajęcia miały na celu zwiększenie zakresów ruchów, poprawę równowagi, zręczności ruchowej i chodzenia. Główny akcent kładziono na umiejętność radzenia sobie w czynnościach codziennych.

Correspondence address: dr Joanna Cholewa, Akademia Wychowania Fizycznego im. J. Kukuczki, ul. Mikołowska 72A, 40-064 Katowice, Polska, e-mail: a.cholewa@awf.katowice.pl

Received: 29.12.2011; accepted: 18.10.2012 
and PDQ-39 score decreased by $17.12 \%$. Mean score of the Schwab and England scale increased by $9.69 \%$, indicating an improved quality of life.

Conclusions: The applied rehabilitation programme decreased the severity of motor symptoms in patients with PD.

Key words: physiotherapy, Parkinson disease, quality of life.

\section{Introduction}

Parkinson disease (PD) is regarded as the second most frequent neurodegenerative disorder, after Alzheimer's disease, and requires continuous, long-term treatment, both pharmacological and non-pharmacological $[1,2]$. Despite the use of the latest medical and surgical methods in treatment of PD, we still observe the progression of disability in patients during the course of disease. Clinical manifestations including stiffness, bradykinesia, tremor, and postural instability lead to difficulties in performing simple motor tasks like walking, standing up and changing position in bed. Such motor disturbances cause loss of independence and worsening of life quality [3].

It is believed that physiotherapy should be applied in addition to pharmacological treatment in $\mathrm{PD}$ [49]. Due to slow progression of disease, physiotherapy in this disease differs from the one used in other diseases. The aim of the therapist is to maximise functional abilities and to minimize secondary complications $[10,11]$. It is easier to sustain function level than to restore functions lost due to inactivity. Therefore, it is necessary to start therapy early and then to continue it regularly [12-14].

Research on effectiveness of physiotherapy in PD [10,11,15-17] provides no reliable evidence that may confirm or deny its influence. Moreover, the research contained many methodological shortcomings such as inappropriate criteria of patients' selection, lack of a control group, unreliable examination tools and lack of objectivity [17]. Therefore, there is still a need to verify the efficiency of physiotherapy in $\mathrm{PD}$ patients $[4,18]$.
Dodatkowo badani otrzymywali zestaw ćwiczeń do samodzielnego codziennego wykonywania w warunkach domowych.

Wyniki: W grupie badanej stwierdzono istotną różnicę w wartościach punktowych poszczególnych skal między stanem wyjściowym i po 12-tygodniowym okresie usprawniania. Zmniejszenie punktacji dotyczyło UPDRS (w części I o 17,31\%, w części II o 22,2\%, a w części III o 18,96\%) oraz PDQ-39 (o 17,12\%). Punktacja w skali Schwaba i Englanda zwiększyła się o 9,69\% (poprawa jakości życia).

Wnioski: Uzyskane wyniki badań wskazują na korzystny wpływ zastosowanego programu rehabilitacyjnego na stopień nasilenia objawów ruchowych u osób z ChP.

Słowa kluczowe: fizjoterapia, choroba Parkinsona, jakość życia.

The aim of this work was to evaluate the influence of systematically applied physiotherapy on motor ability in patients with PD. Additionally, this research tried to estimate the impact of performed functional exercises on daily activities, degree of independence and quality of life.

\section{Material and methods}

Seventy patients with idiopathic PD, treated in the Department of Neurology, Medical University of Silesia in Katowice, were included in the study. The Committee of Bioethics at the University of Physical Education in Katowice granted its permission to carry out such examinations and all participants were informed about the aims and course of research, to which they agreed in writing.

Idiopathic PD was diagnosed by a neurologist (movement disorders specialist) on the basis of criteria set by the United Kingdom Parkinson's Disease Society Brain Bank. Only patients in stage III according to the Hoehn and Yahr scale were included [19]. Patients were randomly divided into two groups: the intervention group and the control group. The intervention group consisted of 40 patients ( 17 females and 27 males), aged $70.2 \pm 5.75$ with disease duration of $8.03 \pm$ 3.41 years. The control group consisted of 30 patients (11 females and 19 males), aged $70.17 \pm 5.38$, and disease duration of $7.33 \pm 2.2$ years. Patients with cognitive dysfunction as well as with depression were excluded from the study. Screening for those neuropsychiatric non-motor symptoms was performed by a neuropsychologist and a psychiatrist. 
The technique of purposeful selection as an experimental method was used in order to monitor causal relationships and dependencies. The clinical state of patients was evaluated based on the Unified Parkinson's Disease Rating Scale (UPDRS), part I - intellectual impairment, part II - activities of daily living, part III - motor examination [20]. Every patient was examined in his/her best motor condition ('on' state). Additionally, rating of daily activities was carried out by applying the Schwab and England Activities of Daily Living scale (ADL) [21]. Next, quality of life was evaluated by The Parkinson's Disease Questionnaire scale (PDQ-39) [22], which consists of 39 questions arranged in eight sub-scale groups as follows: mobility - 10 questions; activities of daily living (ADL) - 6; emotional well being - 6; stigma -4 ; social support -3 ; cognitive impairment -4 ; communication -3 ; and bodily discomfort -3 . The system of 5 -point estimation was from 0 to 4 , where $0=$ $=$ never, $1=$ occasionally, $2=$ sometimes, $3=$ often, $4=$ always. The questions concerned the previous month and presence of PD. Each question had the same beginning: 'Due to Parkinson disease, how often last month did you ...?' The questionnaire was completed by the patients themselves or with the help of an assistant. The result in points was calculated separately for each subscale according to the formula:

Total points for each subscale $\times 100 / 4 \times$ numbers of questions from each subscale.

The summary result of the questionnaire was given in the so-called Summary Index (SI), according to: $\mathrm{PDQ}=$ total points/8. Maximal number of points gained in each subscale amounted to 100 and indicated the worst quality of life. A lower score in this scale indicates better quality of life.

The intervention group participated in rehabilitation exercises twice a week for 60 minutes. Each exercise was functionally justified and aimed at improving everyday activities. Rehabilitation procedures were planned with regards to given symptoms; in bradykinesia and posture instability they were aimed at optimal use of still retained patterns of gained and automatic movements. Procedures included frequent movement repetitions, coupling movements with acoustic movement initiator (step), repeating movements with different frequencies, introducing free movements stimulated by different visual, audio or sensual signals, visualizing movement prior to execution, provoking equivalent movements, realizing improper postures and correcting them. In rehabilita- tion of stiffness, treatment was aimed not at eliminating it, but at decreasing the negative effect of stiffness.

The programme of activity included exercises performed in the supine position concentrated on side stretching of trunk muscles, increasing trunk rotation by moving the lower limb in the opposite direction and the upper limb in the same direction. Exercises performed when lying on the side aimed at anti-rotation of the hip girdle against the shoulder girdle. In the supine position, the exercises are aimed at learning turning round. Exercises performed while sitting up followed by changing position to side sitting and simultaneous bouncing a balloon were to improve coordination, reaching and stretching. Other exercises included changing position from side sitting to straight up supported kneeling (with additional support and themselves); exercises from supported kneeling to standing position, following verbal commands given by the therapist or without such commands; exercises learning to walk - working on length of step and foot-surface distance, widening of walk base, direction changing and concentrating on keeping sequence turn of head, shoulder, and hip towards a given movement direction; visual control signals such as tapes, and boxes placed on the floor were used; learning to walk with pace changing following clapping signals given by the therapist; exercises that help to initiate movement, using sensory control signals; walking exercises using other motor programmes (sticks, bowling pins, balloons); exercises in a sitting position aimed at performing exercises within certain spine segments, learning how to transfer body weight and posture reflexes; learning how to change position from sitting to standing by the Frenkla method at three rates; body posture correction exercises with application of cognitive strategies and consciously keeping upright position with use of mirrors; 'high walking' with elements of reaching.

Rehabilitation procedures in case of tremor consisted of working out strategies decreasing the symptoms. Patients were taught how to diminish tremor by performing purposeful movements such as fixing lower limbs against the chair leg, occipital resting against the wall, or transferring body weight from leg to leg.

Additionally, patients received a set of simple exercises (with pictures) to be performed alone at home. Proposed sets of exercises were worked out by the author of the study on the basis of published works [23-25].

The examinations lasted 12 weeks and rehabilitation exercises were carried out twice a week for 60 minutes. Patients from the control group did not take part in any exercises, either in the gym or at home. The obtained 
Table 1. Comparison of baseline values of tests performed in intervention and control group before the intervention*

\begin{tabular}{|lccccccc|}
\hline Variable & $\begin{array}{c}\text { Intervention } \\
\text { group }\end{array}$ & $\begin{array}{c}\text { Control } \\
\text { group }\end{array}$ & $\begin{array}{c}\text { Absolute } \\
\text { difference }\end{array}$ & $\begin{array}{c}\text { Relative } \\
\text { difference [\%] }\end{array}$ & t-statistic & p-value \\
\hline UPDRS score & & & & & & & \\
\hline part I & $2.60(1.35)$ & $2.50(1.27)$ & -0.10 & -3.85 & 0.57 & 0.14 \\
\hline part II & $15.45(6.52)$ & $15.93(5.02)$ & 0.48 & 3.11 & 0.68 & 0.25 \\
\hline part III & $21.62(7.72)$ & $21.96(5.92)$ & 0.34 & 1.57 & 0.78 & 0.61 \\
\hline parts I-III & $39.67(14.18)$ & $40.40(9.76)$ & 0.73 & 1.84 & 0.74 & 0.42 \\
\hline Schwab-England scale [\%] & $72.25(6.97)$ & $72.66(5.20)$ & 0.41 & 0.57 & 0.11 & 0.40 \\
\hline PDQ-39 & $40.02(14.72)$ & $43.60(13.61)$ & 3.58 & 8.95 & -1.12 & 0.45 \\
\hline
\end{tabular}

*Data are shown as means (standard deviations)

UPDRS - Unified Parkinson's Disease Rating Scale, PDQ-39 - The 39-item Parkinson's Disease Questionnaire

results were analysed statistically: homogeneity of variance in comparative groups by the Levene test, and distribution by the Kolmogorov-Smirnov test.

In order to evaluate the significance of differences between the two examined groups, Student's $t$-test for independent trials was applied. In order to evaluate differences between results obtained by patients in applied scales before and after the 12 -week rehabilitation period, analysis of variance (ANOVA) was applied, with repetitive measurements with regard to group division and improvement programme. Depending on the significance of main effects and interaction, the post-hoc Bonferroni test was used to perform analyses.

\section{Results}

According to the statistical analysis, variables had normal distribution and time and their variances were homogeneous. Examined groups did not differ before starting the experiment, taking into account results from all performed tests (Table 1).

Carried out variance analysis showed a statistically significant difference between examined groups before and after in each performed test (Table 2). Post hoc tests were used to describe the differences.

In the intervention group, statistically significant differences in scores of various scales were observed before and after the 12-week intervention (Table 3). Part I, II, and III in the UPDRS scale allow one to evaluate the patients on a point scale in many aspects. The results of the UPDRS test of part 1 showed a $17.31 \%$ change. The biggest improvement was observed in the range of daily activities in UPDRS, part II, and amounted to $18.96 \%$. Moreover, physical fitness measurement test- ing by the Schwab and England scale together with evaluation of life quality by the PDQ-39 scale revealed a positive influence of the applied improvement programme on the examined group $(9.69 \%$, and $-17.12 \%)$.

In the control group that did not take part in the rehabilitation programme, a decrease of mobility level was observed (Table 4). Statistically significant changes were observed in UPDRS test results in parts I-III combined (4.21\%) and PDQ-39 (5.87\%). Results obtained in other performed tests showed a decrease of relative values, UPDRS, part I by $4 \%$, UPDRS, part II by $4.21 \%$ and UPDRS, part 3 by $44.28 \%$, Schwab and England by $9.69 \%$, but those differences were not statistically significant.

Table 2. Results of analysis of variance

\begin{tabular}{|lcl|}
\hline Factor & F-statistic & P-value \\
\hline UPDRS part I & 9.781 & $0.002^{*}$ \\
\hline UPDRS part I $\times$ group & 24.153 & $0.001^{*}$ \\
\hline UPDRS part II & 49.704 & $0.001^{*}$ \\
\hline UPDRS part II $\times$ group & 109.369 & $0.001^{*}$ \\
\hline UPDRS part III & 43.705 & $0.001^{*}$ \\
\hline UPDRS part III $\times$ group & 110.416 & $0.001^{*}$ \\
\hline UPDRS parts I-III & 82.072 & $0.001^{*}$ \\
\hline UPDRS parts I-III $\times$ group & 195.105 & $0.001^{*}$ \\
\hline Schwab-England & 20.01 & $0.001^{*}$ \\
\hline Schwab-England $\times$ group & 52.85 & $0.001^{*}$ \\
\hline PDQ-39 & 28.273 & $0.001^{*}$ \\
\hline PDQ-39 $\times$ group & 136.646 & $0.001^{*}$ \\
\hline
\end{tabular}

UPDRS - Unified Parkinson's Disease Rating Scale, PDQ-39 - The 39-item Parkinson's Disease Questionnaire 
Table 3. Comparison of assessed variables in intervention group before and after intervention*

\begin{tabular}{|lccccc|}
\hline Variable & $\begin{array}{c}\text { Before } \\
\text { intervention }\end{array}$ & $\begin{array}{c}\text { After } \\
\text { intervention }\end{array}$ & $\begin{array}{c}\text { Absolute } \\
\text { difference }\end{array}$ & $\begin{array}{c}\text { Relative } \\
\text { difference [\%] }\end{array}$ & $\begin{array}{c}\text { Post-hoc test } \\
\text { p-value }\end{array}$ \\
\hline UPDRS score & & & & & \\
\hline part I & $2.60(1.35)$ & $2.15(1.31)$ & -0.45 & -17.31 & 0.001 \\
\hline part II & $15.45(6.52)$ & $12.02(5.26)$ & -3.43 & -22.20 & 0.001 \\
\hline part III & $21.02(7.72)$ & $17.52(6.45)$ & $-4,10$ & -18.96 & 0.001 \\
\hline parts I-III & $39.67(14.18)$ & $31.70(11.85)$ & -7.97 & $-20,09$ & 0.001 \\
\hline Schwab-England scale [\%] & $72.25(6.97)$ & $79.25(5.72)$ & 7.00 & 9.69 & 0.001 \\
\hline PDQ-39 & $40.02(14.72)$ & $33.17(12.62)$ & -6.85 & -17.12 & 0.001 \\
\hline
\end{tabular}

*Data are shown as means (standard deviations)

UPDRS - Unified Parkinson's Disease Rating Scale, PDQ-39 - The 39-item Parkinson's Disease Questionnaire

Table 4. Comparison of assessed variables in control group before and after intervention*

\begin{tabular}{|lccccc|}
\hline Variable & $\begin{array}{c}\text { Baseline } \\
\text { assessment }\end{array}$ & $\begin{array}{c}\text { Assessment } \\
\text { affer 12 weeks }\end{array}$ & $\begin{array}{c}\text { Absolute } \\
\text { difference }\end{array}$ & $\begin{array}{c}\text { Relative } \\
\text { difference [\%] }\end{array}$ & $\begin{array}{c}\text { Post-hoc test } \\
\text { p-value }\end{array}$ \\
\hline UPDRS score & & & & & \\
\hline part I & $2.50(1.27)$ & $2.60(1.27)$ & 0.10 & 4.00 & 0.640 \\
\hline part II & $15.93(5.02)$ & $16.60(5.24)$ & 0.67 & 4.21 & 0.119 \\
\hline part III & $21.96(5.92)$ & $22.90(6.22)$ & 0.94 & 4.28 & 0.059 \\
\hline parts I-III & $40.40(9.76)$ & $42.10(10.35)$ & 1.70 & 4.21 & 0.010 \\
\hline Schwab-England scale [\%] & $72.66(5.20)$ & $71.00(7.58)$ & -1.66 & -2.28 & 0.260 \\
\hline PDQ-39 & $43.60(13.61)$ & $46.16(13.68)$ & 2.56 & 5.87 & 0.001 \\
\hline
\end{tabular}

*Data are shown as means (standard deviations)

UPDRS - Unified Parkinson's Disease Rating Scale, PDQ-39 - The 39-item Parkinson's Disease Questionnaire

\section{Discussion}

The results of our study confirm the usefulness of various physiotherapeutic methods in $\mathrm{PD}$ patients [2628]. The future target is to find the most effective one, which would give the best possible results. Comella et al. [29] showed that exercises performed for four weeks and aimed at improving keeping balance and walking as well as endurance and motor skills resulted in statistically significant improvement of UPDRS part III (motor examination) in 16 PD patients. Efficiency level was measured in comparison to the control group and the results obtained were similar to those obtained by Nieuwboer $e t$ al. [30], who observed improvement in $\mathrm{PD}$ patients after a 3-month rehabilitation which was aimed at reducing specific difficulties during physical activity rather than improving mobility speed. Ellis et al. [15], who carried out research on 68 patients with PD at stage II and III on the Hoehn and Yahr scale, observed a positive influence of performed movement therapy combined with pharmacological one after 6 weeks as compared to the control group with pharmacological therapy only.

Our study, when compared to other similar ones, was based on a decisively higher number of patients, which allows us to provide more reliable results. Physical efficiency was also dealt with in a different way, as the applied physiotherapeutic programme included: efficiency exercises aimed at increasing movement range, improvement of balance, dexterity, walking and ability to deal with everyday activities with the use of steering signals which help the patient to concentrate on basic aspects of mobility performance. Due to that, PD patients can move more easily when provided with outside steering movement signals [31]. Physiotherapeutic exercises were carried out with regard to everyday functional tasks in both low and high positions, e.g. walking, getting up from a sitting position, turning 
round and rolling over on a mattress. Rehabilitation was performed as task training, which seems to be justified as generalisation of training is most effective when there is high similarity between the exercise task and its new variants [32].

In our study, the influence of rehabilitation on activities of daily living as well as on quality of life was evaluated. Quality of life in PD patients depends mainly on the disease progression, which is related to intensity of movement difficulties. Apart from motor difficulties, there are other off-motor symptoms, which significantly decrease quality of life. However, most authors stress coexistence of psychiatric disturbances, especially reactive depression [33]. Additionally, disturbances of sleep and cognitive activities together with coexisting depression lead to a dramatic decrease of quality of life, which has been confirmed by reports [34]. Only patients without depression and without cognitive dysfunction were included in the study. Nevertheless, our patients were not screened for sleep disturbances, which may exist independently from depression and which may also influence patients' quality of life. Although pharmacotherapy is an undeniable issue to improve quality of life, non-pharmacological therapeutic methods should not be underestimated. In this work attention was paid to physiotherapeutic procedures. Cruise et al. [12] examined 28 patients, who performed exercises twice a week for a period of 12 weeks, and found a significant correlation between motor disturbances and quality of life, indicating the profits resulting from controlled movement activities. Those conclusions are confirmed by other authors $[35,36]$.

The obtained results support the view that a planned physiotherapeutic programme, taking into consideration disease stage and possible modifications for changing abilities of PD patients and stressing task training and functional activity together with application of steering signals, significantly improves quality of life.

\section{Conclusions}

Systematically carried out physiotherapy adjusted to the intensity of motor symptoms of PD increases mobility of patients and their abilities in everyday activities. Systematically performed physiotherapy improves quality of life in PD patients.

\section{Disclosure}

Authors report no conflict of interest.

\section{References}

1. Friedman A. Choroba Parkinsona: mechanizmy, rozpoznanie, leczenie. Czelej, Lublin 2005.

2. Sławek J. Levodopa in the treatment of Parkinson disease - yesterday and today. Neurol Neurochir Pol 2012; 46: 63-75.

3. Gleb D.J., Oliver E., Gilman S. Diagnostic criteria for Parkinson's disease. Arch Neurol 1999; 56: 33-39.

4. Goodwin V.A., Richards S.H., Taylor R.S., et al. The effectiveness of exercise interventions for people with Parkinson's disease: a systematic review and meta-analysis. Mov Disord 2008; 23: 631-640.

5. Montgomery J., Erwin B. Rehabilitative approaches to Parkinson's disease. Parkinsonism Relat Disord 2004; 10 (Suppl 1): 43.

6. Morris M.E., Iansek R., Kirkwood B. A randomized controlled trial of movement strategies compared with exercise for people with Parkinson's disease. Mov Disord 2009; 24: 64-71.

7. Opala G., Jasińska-Myga B., Świat M. Diagnostyka różnicowa zespołów parkinsonowskich. Neurologia i Psychiatria 2004; 4: 79-87.

8. Zawistowska A., Cytowicz-Karpiłowska W., Karpiłowski B. Ocena postępowania usprawniającego osób z chorobą Parkinsona. Fizjoterapia Pol 2006; 2: 133-137.

9. Tickle-Degnen L., Ellis T., Saint-Hilaire M.H., et al. Self-management rehabilitation and health-related quality of life in Parkinson's disease: a randomized controlled trial. Mov Disord 2004; 25: 194-204.

10. Deane K.H., Jones D., Ellis-Hill C., et al. A comparison of physiotherapy techniques for patients with Parkinson's disease. Cochrane Database Syst Rev 2001: CD002815.

11. Deane K.H., Jones D., Playford E.D. Physiotherapy for patients with Parkinson's disease: a comparison of techniques. Cochrane Database Syst Rev 2001: CD002817.

12. Cruise K.E., Bucks R.S., Loftus A.M., et al. Exercise and Parkinson's: benefits for cognition and quality of life. Acta Neurol Scand 2011; 123: 13-19.

13. Grochmal S., Zielińska-Charszewska S. Rehabilitacja w chorobach układu nerwowego. PZWL, Warszawa 1990.

14. Kwolek A. Rehabilitacja osób z chorobą Parkinsona. Neurol Neurochir Pol 2003; 5 (Suppl): 211-220.

15. Ellis T., Goede C.J., Feldman R.G., et al. Efficacy of a physical therapy program in patients with Parkinson's disease: a randomized controlled trial. Arch Phys Med Rehabil 2005; 86: 626-632.

16. Goede C.J., Keus S.H., Kwakkel G., et al. The effects of physical therapy in Parkinson's disease: a research synthesis. Arch Phys Med Rehabil 2001; 82: 509-515.

17. Gage H., Storey L. Rehabilitation for Parkinson's disease: a systematic review of available evidence. Clin Rehabil 2004; 18: 463-482.

18. Crizzle A.M, Newhouse I.J. Is physical exercise beneficial for persons with Parkinson's disease? Clin J Sport Med 2006; 16: 422-425.

19. Hoehn M.M., Yahr M.D. Parkinsonism: onset, progression and mortality. Neurology 1967; 17: 427-442.

20. Brusse K., Zimdars S., Zalewski K., et al. Testing functional performance in people with Parkinson disease. Phys Ther 2005; 2: 134-141. 
21. Katz S., Ford A.B., Moskowitz R.W., et al. Studies of illness in the aged. The Index of ADL: a standardized measure of biological and psychosocial function. JAMA 1963; 185: 914-919.

22. Jenkinson C., Heffernan C., Doll H., et al. The Parkinson's Disease Questionnaire (PDQ-39): evidence for a method of imputing missing data. Age Ageing 2006; 35: 497-502.

23. Fries W., Liebenstund I. Rehabilitacja w chorobie Parkinsona. ELIPSA-JAIM s.c., Kraków 2002.

24. Morris M.E. Movement disorders in people with Parkinson disease: a model for physical therapy. Physical Therapy 2000; 80: 578-597.

25. Ludwig E., Annecke R., Löbring E., et al. Choroba Parkinsona. Wydaronictwo eSPe, Kraków 2003.

26. Baatile J., Langbein W.E., Weaver F., et al. Effect of exercise on perceived quality of life of individuals with Parkinson's disease. J Rehabil Res Dev 2000; 37: 529-535.

27. Lokk J. The effects of mountain exercise in Parkinsonian persons - a preliminary study. Arch Gerontol Geriatr 2000, 31: 19-25.

28. Mitchell P.H., Mertz M.A., Catanzaro M.L. Group exercise: a nursing therapy in Parkinson's disease. Rehabil Nursing 1987; 12: 242-245.

29. Comella C.L., Stebbins G., Brown-Toms N., et al. Physical therapy and Parkinson's disease: A controlled clinical trial. Neurology 1994; 44: 376-378.

30. Nieuwboer A., Weerdt W.D., Dom R., et al. The effect of a home physiotherapy program for persons with Parkinson's disease. J Rehabil Med 2001; 33: 266-272.

31. Morris M.E., Iansek R., Matyas T.A., et al. Stride length regulation in Parkinson's disease normalization strategies and underlying mechanisms. BMJ 1996; 119: 551-568.

32. Schmidt R.A. Motor control and learning: a behavioral emphasis. Third edition. Champaign III, Human Kinetics Inc. 1999.

33. Sławek J., Derejko M. Częstość występowania depresji w chorobie Parkinsona. Neurol Neurochir Pol 2002; 36 (Suppl 2): 406.

34. Boczarska-Jedynak M., Opala G. Zaburzenia snu w chorobie Parkinsona. Neurol Neurochir Pol 2005; 39: 380-388.

35. Fiorani C., Mari R., Bartolini M., et al. Occupational therapy increases ADL and quality of life in Parkinsonism patients. Rehabil Physiother 1997; 12: 134-135.

36. Toole R., Hirsch M., Forkink A., et al. The effects of a balance and strength training program on equilibrium in Parkinsonism: a preliminary study. Neurorehabilitation 2000; 14: 165-174. 